\title{
PEMBERDAYAAN MASYARAKAT SEKITAR MASJID CONDROKIRANAN, PANEMBAHAN, KRATON DALAM PROGRAM SENAM SEHAT LANSIA
}

\author{
Oleh : KKN Alternatif Divisi I.C.3 \\ Universitas Ahmad Dahlan Yogyakarta \\ E-mail: Kknalternatif55@gmail.com
}

\begin{abstract}
Ringkasan
Masyarakat lanjut usia atau Lansia merupakan bagian masyarakat yang penting dan perlu diperhatikan kesehatan dan kondisi kejiwaannya. Maka salah satu program KKN UAD difokuskan pada kesehatan jiwa dan jasmani para lansia. Program ini bertujuan untuk menyehatkan badan dan juga menyegarkan jiwa para lansia. Metode pelaksanaan program KKN meliputi: senam sehat pagi hari, dan bercengkrama bersama dihalaman masjid. Dampak dari kegiatan KKN ini adalah: 1) terciptanya kesadaran masyarakat tentang pentingnya kesehatan di usia lanjut, 2) interaksi masyarakat yang lebih dekat untuk mendorong semangat para lansia, serta 3) menciptakan kebiasaan berolahraga pada pagi hari baik sendiri maupun perkelompok.
\end{abstract}

Kata kunci : pemberdayaan, senam lansia, Condrokiranan, kesehatan lansia.

\begin{abstract}
The elderly or the elderly are an important part of society and care about their health and psychological condition. So one of UAD's KKN programs is focused on the mental and physical health of the elderly. This program aims to nourish the body and also refresh the soul of the elderly. Methods of KKN program implementation include: healthy morning exercises, and chatting together at the yard of the mosque. The impact of this KKN activity is: 1) the creation of public awareness about the importance of health in old age, 2) closer community interaction to encourage the elderly spirit, and 3) create exercise habits in the morning either alone or group.
\end{abstract}

Keywords: empowerment, elderly gymnastics, Condrokiranan, elderly health.

\section{A. PENDAhUluan}

Di Indonesia proporsi penduduk berusia lanjut terus membesar. Indonesia termasuk lima besar negara dengan jumlah penduduk lanjut usia terbanyak di dunia yakni mencapai 18,1 juta jiwa pada 2010 atau 9,6\% dari jumlah penduduk (Sensus Penduduk, 2010). Jumlah lansia meningkat di seluruh Indonesia menjadi 15,1 juta jiwa pada tahun 2000 atau 7,2\% dari seluruh penduduk dengan usia harapan hidup 64,05 tahun. Tahun 2006 usia harapan hidup meningkat menjadi 66,2 tahun dan jumlah lansia menjadi 19 juta orang, dan diperkirakan pada tahun 2020 akan menjadi 29 juta orang atau 11,4\% (Riskesdas, 2013).

Dengan bertambahnya jumlah penduduk dan usia harapan hidup lansia akan menimbulkan berbagai masalah antara lain masalah kesehatan, psikologi dan sosial ekonomi. Sebagian besar permasalahan pada lansia adalah masalah kesehatan akibat proses penuaan ditambah dengan masalah lain seperti masalah keuangan, kesepian, merasa tidak berguna dan tidak produktif. 
Kesegaran jasmani cenderung mengalami penurunan seiring dengan bertambahnya usia seseorang. Penurunan semakin terlihat setelah seseorang berusia 40 tahun dan akan menurun $30-50 \%$ pada saat usia lanjut. Salah satu faktor presdisposisi penurunan kesegaran jasmani adalah kurangnya aktivitas fisik seorang lansia biasanya akan mengalami keterbatasan dalam melakukan aktifivitas sehingga cenderung kurang beraktivitas. Terutama dalam melakukan olahraga seperti jogging, jalan sehat dan senam lansia (Akmal, 2012 ).

Senam lansia adalah serangkaian gerak nada yang teratur dan terarah serta terencana yang diikuti oleh orang lanjut usia yang dilakukan dengan maksud meningkatkan kemampuan fungsional raga untuk mencapai tujuan tersebut. (Santoso, 2010). Dalam Indonesia Nursing (2008) senam lansia disamping memiliki dampak positif terhadap peningkatan fungsi organ tubuh juga berpengaruh dalam meningkatkan imunitas dalam tubuh manusia setelah latihan teratur dan juga meningkatkan semangat secara psikologis.

Berdasarkan permasalahan tersebut, maka ditetapkan tujuan program KKN ini adalah memberdayakan masyarakat sekitar Masjid Condrokiranan terutama para lansia akan pentingnya senam sehat lansia.

\section{B. METODE PELAKSANAAN}

Untuk mencapai tujuan yang diharapkan, program KKN di Masjid Condrokiranan dilakukan dengan pemberdayaan masyarakat melalui praktek langsung. Ringkasan metode pelaksanaan beserta jam kerja efektif mahasiswa (JKEM) tersaji pada table 1 .

Tabel 1. Metode, kegiatan, JKEM dan keterlibatan mahasiswa

\begin{tabular}{|c|c|l|c|c|}
\hline No & Metode & \multicolumn{1}{|c|}{ Kegiatan } & JKEM & $\begin{array}{c}\text { Jumlah } \\
\text { mahasiswa } \\
\text { yang terlibat }\end{array}$ \\
\hline 1 & Praktek & $\begin{array}{l}\text { Menyelenggarakan senam lansia } \\
\text { dengan di bimbing oleh instruktur } \\
\text { senam yang berpengalaman }\end{array}$ & $\begin{array}{c}1 \times 90 \\
\text { menit }\end{array}$ & 9 \\
\hline 2 & Istirahat & $\begin{array}{l}\text { Pendinginan, bercengkrama sesama } \\
\text { masyarakat dan menyantap snack }\end{array}$ & $\begin{array}{l}1 \times 30 \\
\text { menit }\end{array}$ & \\
& & & & 9 \\
\hline
\end{tabular}


Diterbitkan oleh Lembaga Pengabdian kepada Masyarakat

Universitas Ahmad Dahlan Yogyakarta

\section{HASIL, PEMBAHASAN DAN DAMPAK}

a. Gambaran Pelaksanaan
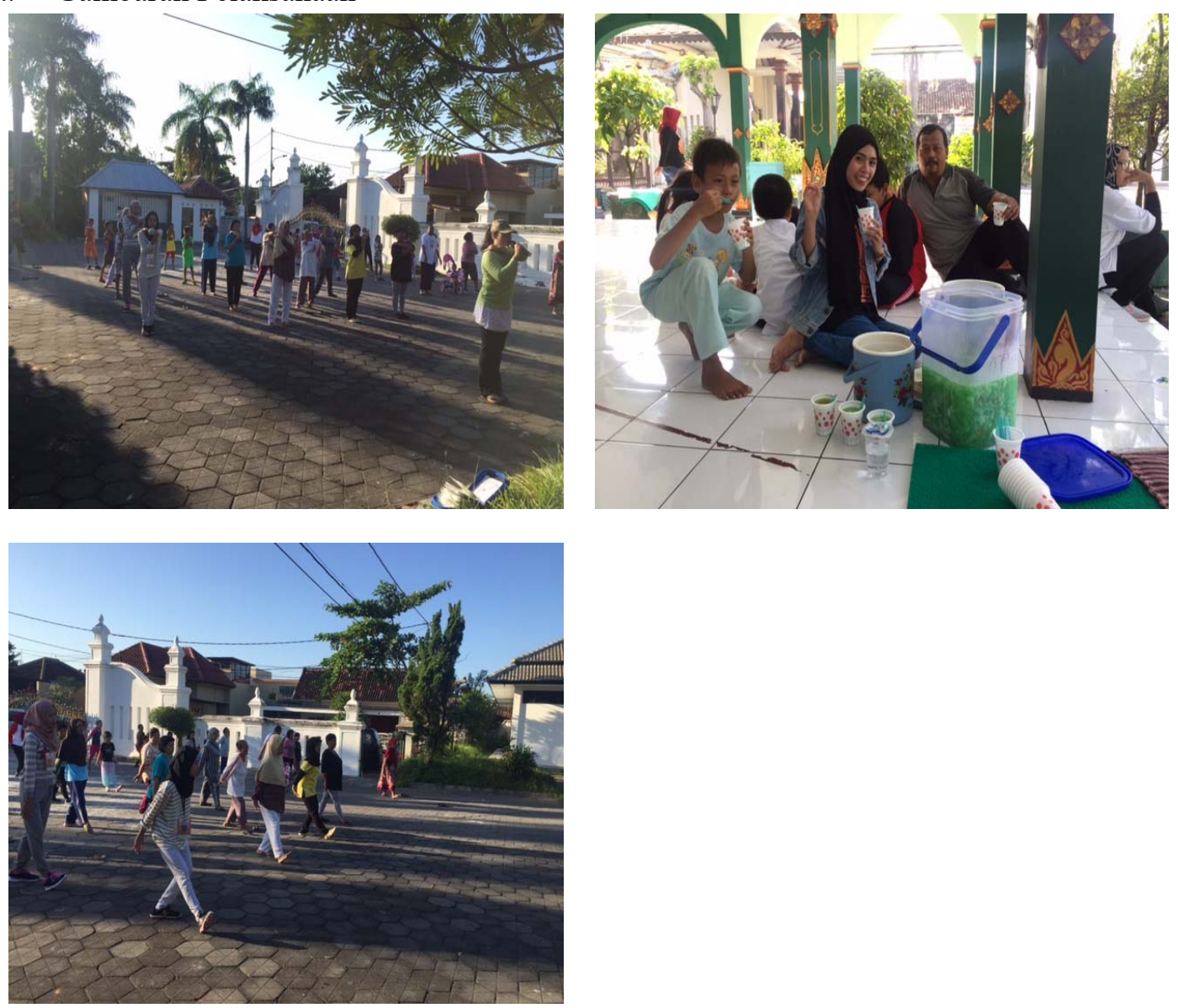

Gambar 1. Aktivitas senam sehat lansia oleh KKN UAD dengan masyarakat di halaman masjid Condrokiranan

Dari gambar 1, diatas terlihat program KKN di sekitar masjid Condrokiranan dapat terlaksana dengan partisipasi masyarakat yang cukup tinggi, yang dengan kata lain program yang dilaksanakan untuk memberdayakan masyarakat khususnya lansia dapat berjalan dengan baik. Program ini berdampak terhadap, 1) terciptanya kesadaran masyarakat tentang pentingnya kesehatan di usia lanjut, 2) interaksi masyarakat yang lebih dekat untuk mendorong semangat para lansia 3) menciptakan kebiasaan berolahraga pada pagi hari baik sendiri maupun perkelompok. 


\section{KESIMPULAN}

Program KKN UAD dalam memberdayakan masyarakat untuk membiasakan warga khususnya lansia dalam melakukan senam sehat lansia di halaman masjid Condrokiranan berjalan dengan baik.

\section{DAFTAR PUSTAKA}

Akmal, Hilda Fauzia, 2012, "Perbedaan Asupan Energi, Protein, Aktivitas Fisik Dan Status Gizi Antara Lansia Yang Mengikuti Dan Tidak Mengikuti Senam Bugar Lansia", Laporan Akhir Hasil Penelitian. Universitas Diponegoro. Semarang.

Santoso, 2010, Senam Lansia Indonesia. Binakarya. Jakarta.

Riset Kesehatan Dasar (Riskesdas), 2013, Badan Penelitian dan PengembanganKesehatan Kementerian RI tahun 2013.

http://www.depkes.go.id/resources/download/general/Hasil\%20Riskesdas\%202013.pdf. (Diakses pada tanggal 5 Juni 2017, Yogyakarta). 